\title{
Resource utilization pattern and rural livelihood in Nanda Devi Biosphere Reserve buffer zone villages, Uttarakhand, Himalaya, India
}

\author{
Prakash Tiwari \& Bhagwati Joshi
}

Keywords: conflicts between local population and protected areas, land-use dynamics, woollen handicrafts, medicinal plants, alternative livelihoods, traditional resource use pattern, land-use intensifications, transhumance, subsistence agriculture, inclusive development

\section{Abstract}

Nanda Devi Biosphere Reserve in Uttarakhand, Himalaya, carries a large human population that traditionally depends on protected area forests, not only to fulfil basic resource needs but also for their livelihood. Due to restricted access to forests, resource utilization patterns have changed and communities have lost their traditional livelihood. This paper aims at investigating resource utilization patterns and rural livelihoods under changed socio-economic conditions and changed availability of and access to resources. Necessary data was generated through remote sensing techniques, ground validation and mapping, observations, monitoring, and socio-economic surveys. The study revealed a decline in forests and an increase in cultivated land due to changes in resource use patterns and resultant land-use intensifications. Availability per capita of forests and pastures declined by $0.72 \%$ and $0.27 \%$ respectively, wool production fell by $47 \% ; 13 \%$ of the people lost their livelihood from forestry and $39 \%$ in the woollen handicraft production sector. Now, subsistence agriculture constitutes the main source of livelihood, as indicated by a $16 \%$ increase in dependency on agriculture, despite a drastic decline in the cultivated land available per capita. Agricultural productivity is fairly low and the region faces an average annual food deficit of $93 \%$, leading to further intensification in agriculture and community unsustainability in the region.
Profile

Protected area

Nanda Devi Biosphere

Reserve

Mountain range

Himalayas

Country

India

\section{Introduction and background}

Conflicts between the local population and protected areas arise in developing countries mainly due to an insensitivity of the management to both genuine and irrational demands of people (Rao et al. 2000). It is not feasible to manage large protected areas on a sustainable basis without considering the needs and problems of local communities, particularly when their traditional activities are limited or prohibited by protection efforts. Nevertheless, the role of local people in the conservation process is ill-defined, both in policy and in practice, leading to conflicts between management and local people (Kuhn 2000; Lynagh \& Urich 2002). Very often, local people oppose protected areas because their traditional livelihood opportunities are threatened (Batisse 1997; Brown 2002). Nanda Devi Biosphere Reserve provides a striking example of one such conflict between people and protected areas in high mountain ecosystems (Bosak 2008). It is therefore imperative to analyse all crucial issues related to the management of protected areas in a holistic manner, considering protected area management as one of the essential components of overall land use and resource development policy, so as to evolve an inclusive framework for the conservation of protected areas as well as for the sustainable development of local people.

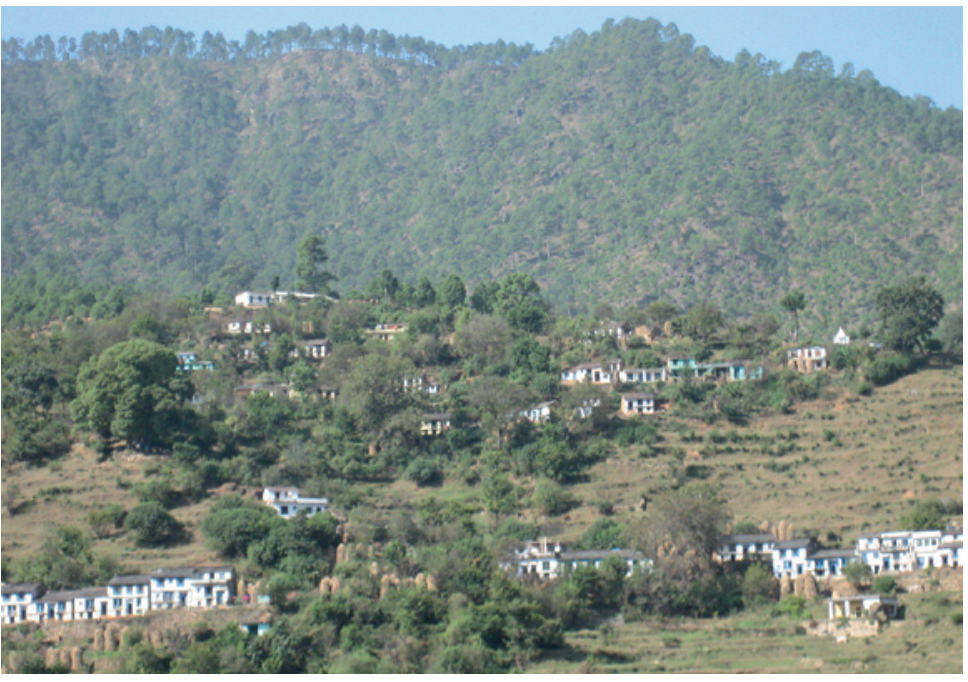

Traditional village in Nanda Devi Biosphere Reserve (NDBR)

\section{Nanda Devi Biosphere Reserve}

Nanda Devi Biosphere Reserve (NDBR) was created in 1988 under the UNESCO Man and the Biosphere Program (MAB) in Nanda Devi National Park (established in 1982 for an area of $2236.74 \mathrm{~km}^{2}$ ) Later, in 2000, NDBR was extended to the Valley of Flowers National Park (created in 1982 for an area of $\left.1874.28 \mathrm{~km}^{2}\right)$ and its adjoining area $\left(1749.67 \mathrm{~km}^{2}\right)$, 


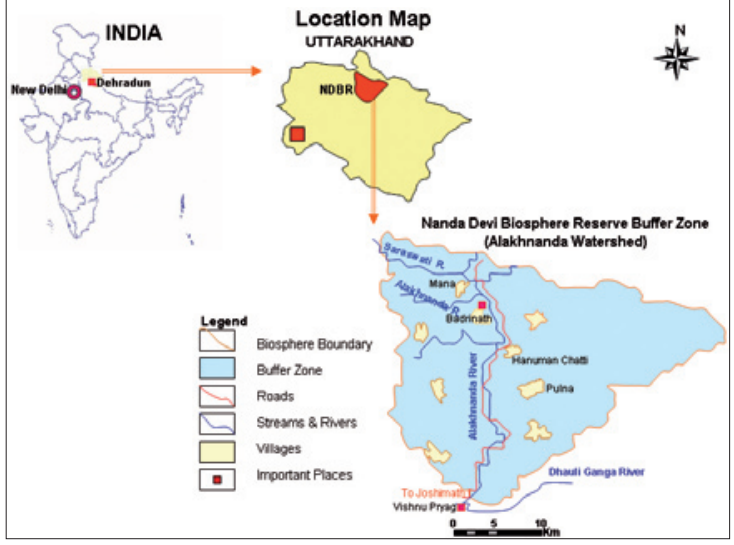

Figure 1 - Location map of NDBR

bringing the total area of the reserve to $5860.68 \mathrm{~km}^{2}$ across Great Himalayan ranges at an altitude ranging from $1900 \mathrm{~m}$ to $7817 \mathrm{~m}$ (Wildlife Institute of India 1998, 2001). At present, NDBR is constituted by two core zones - (i) Nanda Devi National Park $\left(624 \mathrm{~km}^{2}\right)$, and (ii) Valley of Flowers National Park $\left(87.50 \mathrm{~km}^{2}\right)-$ and a buffer zone of $5149.18 \mathrm{~km}^{2}$. Given the specific significance of Nanda Devi Biosphere Reserve within high altitude biosphere reserve systems, UNESCO awarded NDBR the status of World Heritage Site in 1992. NDBR stretches across the Chamoli, Bageshwar and Pithoragarh districts of the newly established Himalayan state of Uttarakhand (Figure 1). In total, there are 47 villages in the NDBR buffer zone, mainly inhabited by tribal communities.

\section{Methodology}

The present study is confined to nine villages in the NDBR buffer zone of the Alakhnanda river catchment area $\left(1786 \mathrm{~km}^{2}\right)$. Remote sensing techniques were employed to interpret land use and its dynamics and to appraise natural resources. Digital interpretation of high resolution Linear Imaging Self-Scanning III (LISS-III) and Panchromatic (PAN) merged data of the Indian

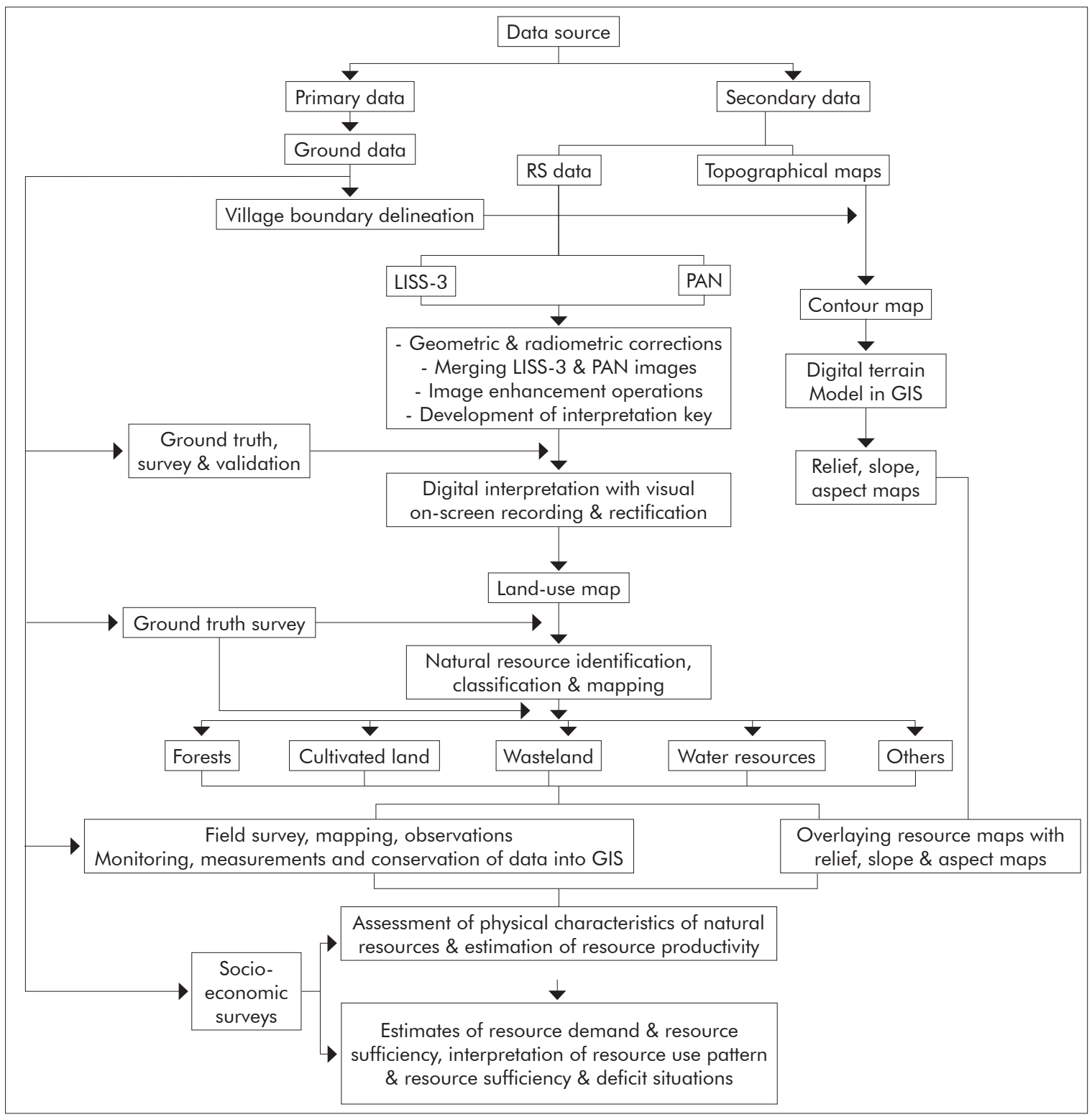

Figure 2 - Methodology for resource analysis 
Remote Sensing Satellite (IRS) was carried out and visual interpretation keys were prepared for primary land-cover/land-use classification based on intensive ground validation. This was followed by digital classification of land cover/land use and appraisal of natural resources through on-screen visual recording and adjustment, and the generated data were transformed into GIS. The interpretation of satellite data was followed by an intensive reconnaissance survey to prepare final land-use and resource maps. In order to monitor land-use dynamics, landuse maps from 1978 and 2008 were used as spatial layers and the land-use changes identifed with the help of GIS. Use of resources and rural livelihood structure were analysed by interpreting information generated from social surveys using exclusively designed schedules and questionnaires. Resource deficit, sufficiency and surplus situations were analysed by developing estimates of production and demand at household level (Figures $2 \& 3$ ).

\section{Traditional society and livelihood conflicts}

The human population in NDBR is confined to the buffer zone of the reserve and is dominated by the Bhotia tribal community. Bhotia is a generic term that refers to the bulk of the population that originated from Tibet and inhabits Great Himalayan ranges in the Uttarakhand districts of Bageshwar, Pithoragarh, Chamoli and Uttarkashi (Badola 1995; Hoon 1996). Bhotia speak Tibeto-Burman dialects, and there are several distinct groups of Bhotia people. These are Jadhs in Uttarkashi district, Marcha (traders) and Tolcha (farmers) in Chamoli district, and Shaukas in Pithoragarh district (Nand \& Kumar 1989). The NDBR in the Alakhnanda catchment area is inhabited by Tolcha and Marcha Bhotias. As in other parts of Uttarakhand, Bhotia in NDBR are semi-nomadic and practise transhumance (Badola 1995).

The total population of the study area numbers 2107 persons, who are spread across nine villages and 271 households. For centuries, the economy of local communities depended on trade with Tibet, which not only contributed significantly to the economic development of the region, but also enriched cultural diversity through the exchange of various items of daily use. Trade with Tibet, however, ceased after the Sino-Indian border conflict in 1962, which was a major setback for the local economy. Supplementary sources of rural livelihood were the cultivation of food and cash crops, fruit and nuts, the products of woollen handicrafts, and collecting medicinal and aromatic plants (Silori \& Badola 2000). In addition, mountaineering and trekking on Nanda Devi provided a viable means of livelihood to local people as porters and guides until 1982, when the Nanda Devi area $\left(624 \mathrm{~km}^{2}\right)$ was designated as Nanda Devi National Park. Subsequently, all expeditions and tourist activities were prohibited and access to forests was restricted.

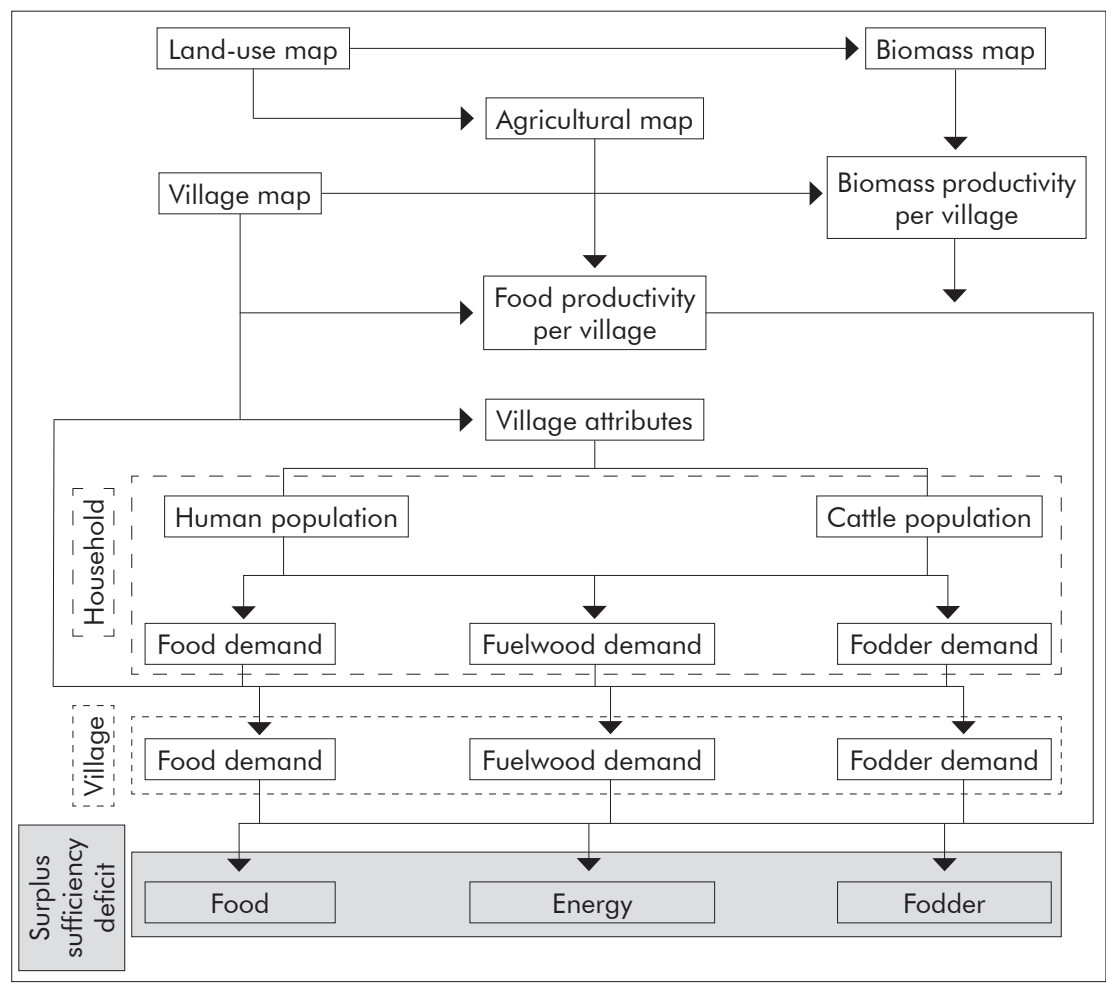

Figure 3 - Methodology for the analysis of resource sufficiency and deficit situations

Conflicting ideas about livelihood and conservation policies on the part of policy makers and local people constitute the main source of current disagreements in the NDBR (Batisse 1997; Brown 2002). There are several reasons for the increase in conflicts between local people and NDBR management.

These include

- failure to consider alternative and viable means of livelihood,

- loss of livelihood opportunities due to the ban on tourism in the core zone,

- livestock and crop depredation caused by wildlife, non-involvement of local people in actual decisionmaking processes (Rao et al. 2000).

The conflicts around the NDBR are very complex as the entire population living in the buffer zone completely depends on forests to fulfil its various resource needs (Rao et al. 2006; Silori 2007). Traditionally the people enjoyed access to forest resources, but, after the creation of the Nanda Devi National Park in 1982 and the biosphere reserve in 1988, their traditional rights to use this resource were curtailed. As a result, forests and pastures became rapidly depleted due to overgrazing in the limited available area, livestock numbers and wool production declined and threatened traditional livelihoods. Moreover, the ban on tourism in the core zone has not only endangered livelihood and community sustainability but also created a source of continued conflict between local people and management authorities. The ban on tourism is of greatest concern to the local people as it adversely affects their rural subsistence economy (Bosak 2008). As a result, wellintentioned conservation measures have undermined 


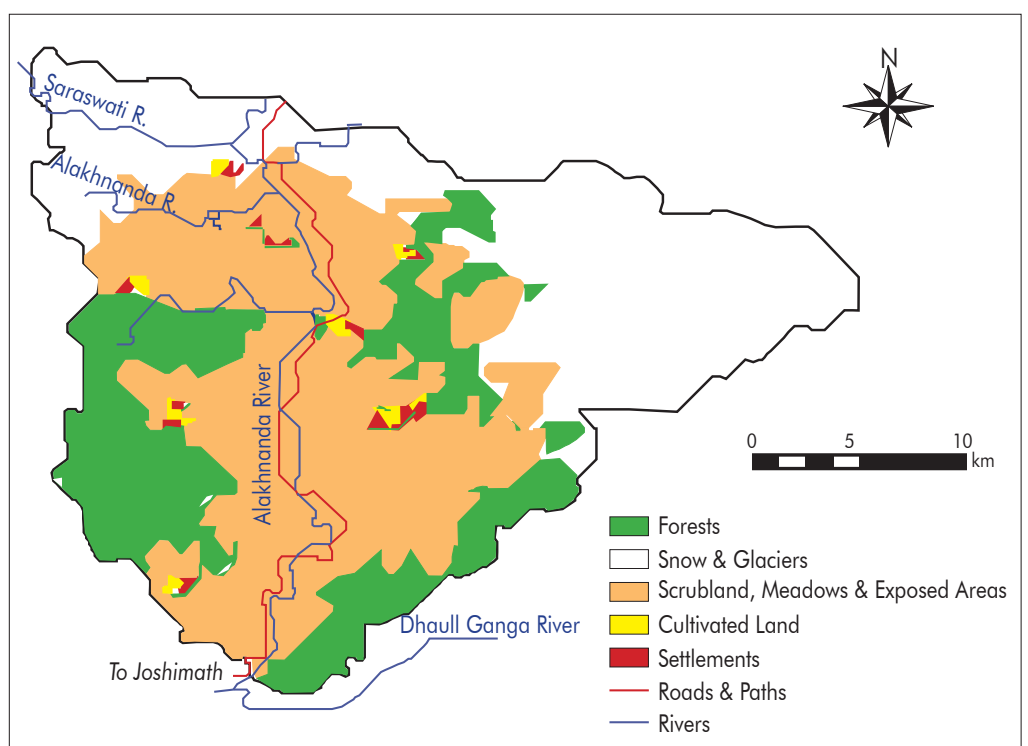

Figure 4 - Broad land-use-pattern in NDBR in 2008

the sustainability, economy and culture of the very communities that have preserved the landscape for thousands of years (Kainthola 2005).

\section{Land use and its dynamics}

In $2008,211.91 \mathrm{~km}^{2}$ or $11.87 \%$ of the investigated area $\left(1786 \mathrm{~km}^{2}\right)$ of the NDBR buffer zone was forest; $677.24 \mathrm{~km}^{2}$ or $37.92 \%$ was snow-covered; $20.50 \mathrm{~km}^{2}$ or $1.15 \%$ was cultivated; $813.20 \mathrm{~km}^{2}$ or $45.53 \%$ was classified as exposed area, scrub and alpine meadows; $60.77 \mathrm{~km}^{2}$ or $3.40 \%$ was covered by water; and $2.38 \mathrm{~km}^{2}$ or $0.13 \%$ was settlements, roads and paths (Table $2 \&$ Figure 4). A study of land use dynamics carried out for the period from 1978-2008 revealed that the areas of forest and snow-cover decreased by $2.54 \%$ and $4.89 \%$ respectively, whereas the

Table 1 - Land-cover / Land-use changes in NDBR buffer zone (1978-2008)

\begin{tabular}{|l|r|r|r|}
\hline Land-use category & $\begin{array}{r}\text { Area in } \mathbf{~ k m}^{2} \\
\mathbf{( 1 9 7 8 )}\end{array}$ & $\begin{array}{r}\text { Area in } \mathbf{~ k m}^{2} \\
\mathbf{( 2 0 0 8 )}\end{array}$ & $\begin{array}{r}\text { Percent change } \\
\text { (1978-2008) }\end{array}$ \\
\hline Forests & 257.34 & 211.91 & -2.54 \\
\hline Snow-covered area & 764.58 & 677.24 & -4.89 \\
\hline Cultivated land & 18.50 & 20.50 & +0.11 \\
\hline Scrubs, meadows \& exposed areas & 684.50 & 813.20 & +7.21 \\
\hline Bodies of water & 59.61 & 60.77 & +0.06 \\
\hline Settlements \& roads & 1.47 & 2.38 & +0.05 \\
\hline Total & $\mathbf{1 7 8 6 . 0 0}$ & $\mathbf{1 7 8 6 . 0 0}$ & $\mathbf{7 . 4 3}$ \\
\hline
\end{tabular}

Table 2 - Natural resource profile in NDBR buffer zone

\begin{tabular}{|l|r|r|}
\hline Natural resources & $\begin{array}{r}\text { Area in } \mathbf{~ k m}^{\mathbf{2}} \\
\mathbf{( 2 0 0 8 )}\end{array}$ & $\begin{array}{r}\text { Percent } \\
\text { of total area }\end{array}$ \\
\hline Forests & 211.91 & 11.87 \\
\hline Snow-covered area & 677.24 & 37.92 \\
\hline Cultivated land & 20.50 & 1.15 \\
\hline Scrubs & 356.24 & 19.95 \\
\hline Meadows & 265.12 & 14.84 \\
\hline Exposed areas & 191.84 & 10.74 \\
\hline Bodies of water & 60.77 & 3.40 \\
\hline Total & $\mathbf{1 7 8 3 . 6 2}$ & $\mathbf{9 9 . 8 7}$ \\
\hline
\end{tabular}

area in cultivation increased by $0.11 \%$, water-bodies by $0.06 \%$, settlements and roads by $0.05 \%$, and alpine meadows and scrub by $7.21 \%$ (Table 1 ).

\section{Natural resources}

Snow, water, forests, alpine meadows, high-altitude scrubland and cultivated land make up the natural resource base of the investigated area of the NDBR buffer zone. Snow, glaciers and water resources account for more than $41 \%$ of the total resource base of the region. There are about 34 medium and small glaciers in the region. They not only form the source of all streams and rivers, but also serve as natural regulators of water. The region constitutes part of Asia's biggest water reservoir. Average annual discharge of water in the region ranges from 37.78 to $95.21 \mathrm{~m}^{3} / \mathrm{sec}$. The total regional resource base in the study area of the NDBR buffer zone consists of $11.88 \%$ forests, $19.95 \%$ high-altitude scrubland and $14.84 \%$ alpine meadows. Approximately $1.15 \%$ has been classified as cultivated land (Table 2).

\section{Forest resources and livelihood}

The forests of the region have been essential for the development of its economy, culture, traditions and history. Almost $12 \%$ of the total resource base of the study area of the NDBR buffer zone consists of forests, predominantly of sub-alpine, alpine and transhimalayan vegetation types. A large part of this zone is covered by high-altitude pastures, locally known as Buggyals. In terms of their administration, the forests of the region are classified into

- reserved forests, managed by the State Forest Department,

civic forests, managed by the Revenue Department,

- Panchayat forests, maintained in the oldest form of participatory forest management, introduced by the British at village level in India.

By far the biggest proportion (91\%) of the forests in the buffer zone is reserved forests. The entire region is very rich in floral diversity and a variety of extremely rare plants and herbs with very high medicinal, aromatic and economic value grow naturally in forests, scrubland and other areas of the buffer zone.

Since traditional resource utilization structure in the region is closely interlinked with forests, farmland and livestock, natural forests carry a large human population, including forest-dependent aboriginal communities living interspersed in them (Mitchell 1979; Tiwari 1995). Forests are therefore the most fundamental and critical natural resource in the region, and local people largely depend on forests, not only for fulfilment of basic resource needs, but also for their livelihood ( $\mathrm{Ti}$ wari \& Joshi 1997; Tiwari 2000, 2008). In view of this, local communities were entitled to utilize forests to fulfil their various resource demands. As they had done 
Table 3 - Forest productivity, efficiency and resource flow pattern in NDBR buffer zone (1978 and 2008)

\begin{tabular}{|c|c|c|c|c|c|c|c|c|c|c|c|c|}
\hline \multirow[t]{2}{*}{ Villages } & \multicolumn{3}{|c|}{$\begin{array}{r}\text { Community forests } \\
\text { (ha) }\end{array}$} & \multicolumn{3}{|c|}{$\begin{array}{r}\text { Forest per capita } \\
\text { (ha) }\end{array}$} & \multicolumn{3}{|c|}{$\begin{array}{l}\text { \% People earning their } \\
\text { livelihood by forestry }\end{array}$} & \multicolumn{3}{|c|}{$\begin{array}{r}\text { \% People earning their } \\
\text { livelihood from medicinal } \\
\text { plants \& herbs }\end{array}$} \\
\hline & 1978 & 2008 & $\%$ Change & 1978 & 2008 & $\%$ Change & 1978 & 2008 & $\%$ Change & 1978 & 2008 & $\%$ Change \\
\hline Badrinath & 11 & 7 & -36 & 0.79 & 0.02 & -0.77 & 45 & 29 & -16 & 11 & 3 & -8 \\
\hline Bamni & 33 & 27 & -18 & 0.91 & 0.17 & -0.74 & 39 & 27 & -12 & 27 & 7 & -20 \\
\hline Bhyundar & 44 & 40 & -9 & 0.71 & 0.25 & -0.46 & 37 & 31 & -6 & 25 & 9 & -16 \\
\hline H. Chatti & 38 & 31 & -18 & 0.95 & 0.15 & -0.80 & 41 & 25 & -16 & 9 & 6 & -3 \\
\hline Khairo & 40 & 25 & -38 & 0.75 & 0.28 & -0.47 & 49 & 31 & -18 & 10 & 7 & -3 \\
\hline Lambagar & 45 & 35 & -22 & 1.07 & 0.38 & -0.69 & 51 & 45 & -6 & 8 & 2 & -6 \\
\hline Mana & 33 & 19 & -29 & 0.59 & 0.11 & -0.48 & 44 & 32 & -12 & 21 & 15 & -6 \\
\hline Pulna & 48 & 41 & -15 & 1.67 & 0.56 & -1.11 & 47 & 29 & -18 & 7 & 4 & -3 \\
\hline Painka & 37 & 31 & -16 & 1.26 & 0.34 & -0.92 & 38 & 28 & -10 & 22 & 15 & -7 \\
\hline Total & 329 & 256 & -22 & 0.97 & 0.25 & -0.72 & 43 & 31 & -13 & 16 & 8 & -8 \\
\hline
\end{tabular}

for centuries, they used the forests to rear sheep and livestock for wool and woollen products, meat, manure and as a source of paid work, for cultivating food and cash crops and for collecting medicinal plants, in short, as the main source of livelihood for local communities. After the creation of NDBR, however, these utilization rights and concession were withdrawn.

The closure of the core zone forced the communities to abandon their traditional livelihood pattern. As a result, the traditional resource utilization pattern changed, and forest resources became drastically depleted due to land-use intensification. Different villages of the study area recorded decreases in available community forests (civil and Panchayat forests) ranging from $9 \%$ to $38 \%$, with an overall decline of $22 \%$ between 1978 and 2008. Similarly, per capita availability of forests also declined by between $0.46 \%$ and $1.11 \%$. The study revealed that the depletion of forest resources adversely affected forest-based livelihood in the region. On average, $13 \%$ of people lost their livelihood within the last 30 years (Table 3). Restrictions on community access to forests and the resultant pressure on the limited available forest resources also reduced the availability of medicinal plants, and with it, the livelihood of $3 \%$ to $15 \%$ of the people (Table 3 ). However, people in some villages have started cultivating these plants on their private land. However, radical changes in the agricultural system are required to produce medicinal and aromatic plants suited to local conditions (Rao et al. 2000). Nearly $8 \%$ of the households of the nine villages are currently engaged in collecting medicinal plants. This activity contributes about $7 \%$ of the annual rural income in the region. There is clearly a large scope for systematic cultivation of medicinal plants in the region. So far this has been obstructed by a lack of technical knowledge, poor infrastructural facilities and an inefficient marketing system.

As mentioned earlier, grazing of sheep and goats on high-alpine meadows constitutes an important source of livelihood in the region. With the closure of pastures, however, the available grazing area decreased and most households decided to abandon the practice. This has had an enormous adverse impact on the production of wool and woollen products which previously constituted one of the core components of rural livelihood. Table 4 shows that, on average, the available pasture per head of cattle declined by 0.27 ha, wool production fell by $47 \%$, and $39 \%$ people lost their livelihood. The average available grazing land per cattle in the study area stands at about 0.33 ha against a minimum of 3.5 ha as recommended by Singh et al. (1984) for the Himalayas. On average, the region is currently fac-

Table 4 - Decline in pasture and woollen handicraft livelihood in NDBR buffer zone villages

\begin{tabular}{|l|r|r|r|r|r|}
\hline Villages & \multicolumn{2}{|r|}{$\begin{array}{r}\text { Available pasture per head } \\
\text { of cattle (in ha) }\end{array}$} & $\begin{array}{r}\text { \% Decline in } \\
\text { wool production } \\
(\mathbf{1 9 8 2 - 2 0 0 8 )}\end{array}$ & $\begin{array}{r}\text { \% Decline in woollen } \\
\text { handicraft-based livelihood } \\
\text { (1982-2008) }\end{array}$ \\
\cline { 2 - 4 } & $\mathbf{1 9 8 2}$ & $\mathbf{2 0 0 8}$ & Change (ha) & 21 \\
\hline Badrinath & 0.27 & 0.11 & $-0,16$ & 45 & 14 \\
\hline Bamni & 0.51 & 0.24 & -0.27 & 27 & 17 \\
\hline Bhyundar & 0.71 & 0.32 & -0.39 & 35 & 22 \\
\hline H. Chatti & 0.47 & 0.22 & -0.25 & 29 & 65 \\
\hline Khairo & 0.71 & 0.34 & -0.37 & 71 & 51 \\
\hline Lambagar & 0.72 & 0.41 & -0.31 & 51 & 70 \\
\hline Mana & 0.69 & 0.51 & -0.18 & 74 & 34 \\
\hline Pulna & 0.76 & 0.54 & -0.22 & 29 & 59 \\
\hline Painka & 0.58 & 0.32 & -0.26 & 61 & 39 \\
\hline Average & $\mathbf{0 . 6 0}$ & $\mathbf{0 . 3 3}$ & $-\mathbf{0 . 2 7}$ & $\mathbf{4 7}$ & 5 \\
\hline
\end{tabular}

Table 5 - Forest productivity, sufficiency and resource flow pattern in NDBR buffer zone

\begin{tabular}{|l|r|r|r|r|}
\hline Villages & $\begin{array}{r}\text { Fuelwood sufficiency } \\
\text { in (\%) }\end{array}$ & $\begin{array}{r}\text { Distances (km) in- } \\
\text { volved in fuelwood } \\
\text { collection }\end{array}$ & $\begin{array}{r}\text { Fodder suf- } \\
\text { ficiency in (\%) } \\
\text { deficit/surplus }\end{array}$ & $\begin{array}{r}\text { Distances (km) } \\
\text { involved in fodder } \\
\text { collection }\end{array}$ \\
\hline Badrinath & -24.10 & $0.5-2.0$ & -21.30 & $0.5-1.0$ \\
\hline Bamni & -17.56 & $0.5-2.0$ & -22.33 & $0.5-2.0$ \\
\hline Bhyundar & +11.14 & $0.5-1.0$ & +08.51 & $0.5-1.0$ \\
\hline H. Chatti & -21.35 & $0.5-3.0$ & -27.30 & $0.5-2.0$ \\
\hline Khairo & -18.54 & $0.5-3.0$ & -15.44 & $0.5-2.0$ \\
\hline Lambagar & +14.20 & $0.5-2.0$ & +24.25 & $0.5-1.0$ \\
\hline Mana & -45.25 & $0.5-4.0$ & -37.22 & $0.5-2.0$ \\
\hline Pulna & +10.05 & $0.5-2.0$ & +12.14 & $0.5-1.0$ \\
\hline Painka & -24.10 & $0.5-4.0$ & -26.15 & $0.5-2.0$ \\
\hline Average & -12.83 & & -11.65 & \\
\hline
\end{tabular}



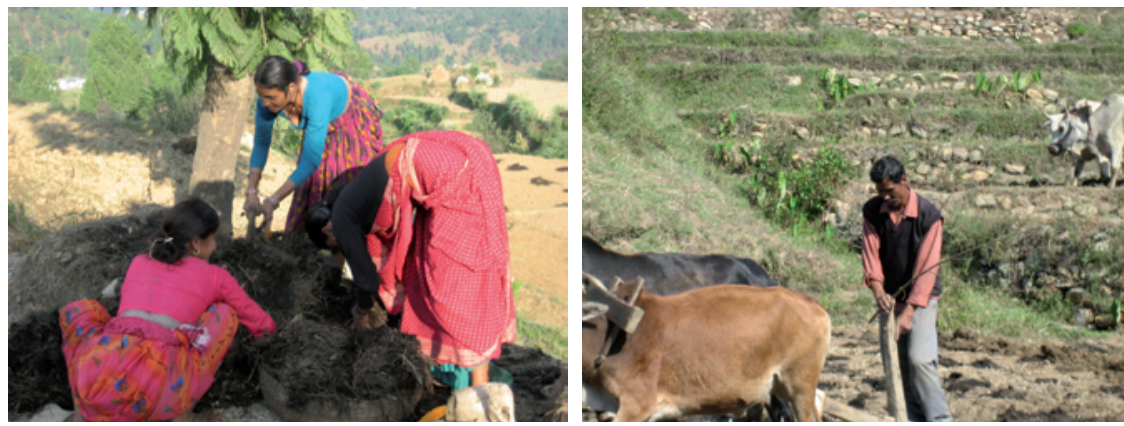

Left: women preparing to carry compost to the fields. Right: ploughing with traditional plough

\section{Subsistence agriculture as a source of livelihood}

Restricted access to forests transformed the traditional livelihood structure in the region, and after the creation of NDBR, subsistence agriculture became the main source of livelihood. The study revealed that despite a drastic decline in cultivated land per capita (between 0.04 ha and $1.95 \mathrm{ha}$ ), dependency on agriculture increased by $6 \%$ to $26 \%$ in different villages between 1978 and 2008 (Table 6 \& Figure 5). Approximately

ing a shortage of $12.83 \%$ for fuel wood and $11.65 \%$ for fodder. Travel distances necessary for collecting fuelwood and fodder are $0.5-4 \mathrm{~km}$ and $0.5-2 \mathrm{~km}$ respectively (Table 5). Transhumance is a common practice in the higher Himalayas with limited carrying capacity. Transhumant pastoralists used the resources available in various subsystems for their livelihoods. Transhumance has declined since the creation of NDBR and restrictions on grazing. This has increased the stress on limited forest and pasture resources further (Nautiyal et al. 2003).

Strategies for income generation activities and implementation of alternative livelihood development schemes have evolved within the framework of the Man and the Biosphere (MAB) concept. However, these programmes were formulated with negligible involvement of the people and turned out to be ineffective under local ecological and socio-cultural conditions (Makhuri et al. 2000). Furthermore, local tribal communities were not interested in becoming dependant on government programmes (Bosak 2008). Besides, the government's 'top-down' approach and package of alternative livelihood options were found inappropriate in terms of their ecological sustainability, economic viability and social acceptability. This broke the traditional community relationship with its natural environment and increased aggression in local people towards conservation strategies (Rao et al. 2000; Maikhuri et al. 2001).

Table 6-Development of agricultural livelihood structure in NDBR buffer Zone villages

\begin{tabular}{|l|r|r|r|r|r|r|r|}
\hline Villages & $\begin{array}{r}\text { Total } \\
\text { population } \\
\text { (2008) }\end{array}$ & \multicolumn{2}{|c|}{$\begin{array}{r}\text { Cultivated land (ha) per } \\
\text { capita }\end{array}$} & \multicolumn{2}{|r|}{$\begin{array}{r}\text { Percentage of inhabitants } \\
\text { earning their livelihood } \\
\text { from farming }\end{array}$} \\
\cline { 3 - 9 } & & $\mathbf{1 9 8 2}$ & $\mathbf{2 0 0 8}$ & $\begin{array}{r}\text { Change } \\
\text { (ha) }\end{array}$ & $\mathbf{1 9 8 2}$ & $\mathbf{2 0 0 8}$ & $\begin{array}{r}\text { Change } \\
\text { (\%) }\end{array}$ \\
\hline Badrinath & 711 & 0.09 & 0.04 & -0.05 & 41 & 67 & +26 \\
\hline Bamni & 197 & 1.07 & 0.81 & -0.26 & 37 & 61 & +24 \\
\hline Bhyundar & 177 & 1.68 & 1.05 & -0.63 & 39 & 55 & +16 \\
\hline H. Chatti & 252 & 1.15 & 0.89 & -0.26 & 45 & 57 & +12 \\
\hline Khairo & 144 & 2.85 & 1.95 & -0.90 & 35 & 54 & +19 \\
\hline Lambagar & 119 & 1.70 & 0.98 & -0.72 & 37 & 48 & +11 \\
\hline Mana & 311 & 0.73 & 0.57 & -0.16 & 29 & 35 & +6 \\
\hline Pulna & 86 & 1.24 & 0.85 & -0.39 & 42 & 55 & +13 \\
\hline Painka & 110 & 2.15 & 1.75 & -0.40 & 36 & 53 & +17 \\
\hline Total / Average & $\mathbf{2 1 0 7}$ & $\mathbf{1 . 4 1}$ & $\mathbf{0 . 9 8}$ & $-\mathbf{0 . 4 2}$ & $\mathbf{3 8}$ & $\mathbf{5 4}$ & $+\mathbf{1 6}$ \\
\hline
\end{tabular}
$87 \%$ of households are small farmers with less than 1 ha of land, $7 \%$ are medium-small farmers with land holdings between $1-2 \mathrm{ha}, 5.5 \%$ are medium farmers with land holdings between $2-3 \mathrm{ha}$, and only $0.5 \%$ families can be categorized as large-scale farmers with land holdings of more than 3 ha. Agricultural productivity is fairly low, and the area faces an average annual food shortfall of $93 \%$. As discussed earlier, agriculture never constituted the prime source of livelihood in the region. However, changing socio-economic conditions, mainly the cessation of trade with Tibet, restrictions on traditional practices of resource use, population growth and, of course, land-use dynamics have motivated people to diversify the traditional cropping pattern by bringing more area under cash crops, such as kidney beans, potatoes etc. These crops demand more biomass energy from limited forests. Bosak (2008) observed that it was difficult for small and marginal farmers to survive on the income they got from limited land. This has led to an increase in the intensity of agriculture and to an expansion of arable land on to marginal and sub-marginal lands.

\section{Future options}

The preceding discussion clearly shows that the objective of nature and biodiversity conservation in a protected area like NDBR cannot be attained through top-down and sectoral approaches. It is therefore imperative to analyse all crucial issues for conservation and the protection of nature preserves in a holistic manner by considering protected area management as one of the essential components of overall land use and integrated rural development policy, so as to develop a realistic and inclusive framework for both the management of conservation areas and the sustainable development of rural communities dependent on protected areas (Tiwari \& Joshi 1997). Hence, development of economically viable, ecologically sustainable and socially acceptable alternative means of rural livelihood and active involvement of the communities in the actual decision-making process must form the core components of an integrated conservation and resource management framework for the region. However, the approaches developed for and implemented in protected areas in other ecosystems in India and elsewhere do not lend themselves readily to 
an application on the peculiar ground realities of the complex ecological, social, economic and cultural setting of the NDBR. In the recent past, attempts have been made to implement alternative livelihood development programmes and projects developed within the framework of Man and the Biosphere (MAB) in the region. However, these conservation and development strategies could not win over the local people and proved ineffective, because these schemes did not allow for the active involvement of local people and did not incorporate their local socio-cultural peculiarities in the developmental frameworks (Makhuri et al. 2000; Joshi 2006). The crux of the problem lies in the differing perceptions and attitudes of key stakeholders. The protected area managers stress that the reserve is significant for its unique biodiversity and must be conserved. However, the local people perceive the area as a sacred landscape and prime source of their livelihoods and culture. This clearly shows the complete lack of understanding arising from wellintentioned policies which often creates conflicts (Bosak 2008). Bosak (2008) rightly observed that "in this case, helping policy makers understand that Bhotiya ideas of resource management are based on ideas of exchange with a sacred landscape - a landscape that they identify with through communal livelihoods and other daily activities - may serve to create conservation policies that will accommodate local people and help to preserve biodiversity. However, policy makers must be willing to accept and try to understand multiple concepts of nature and to empower local people with resource management schemes that reflect those local concepts of nature".

This clearly underlines the need for developing an integrated, holistic, community-oriented and absolutely participatory resource management strategy for the protected area, a strategy that respects and incorporates the local environment, culture, traditions, customs and traditional interaction between humans and nature. Core components of such inclusive development and conservation framework should include

- a comprehensive database of natural resources to be established for all the villages of the buffer zone using a Geographic Information System (GIS). The database should build on detailed analysis, appraisal and mapping of natural resources and take into account their natural and socio-economic parameters. This would help local government agencies in developing ecologically sustainable and economically viable alternative livelihood options for the local population as well as in designing priority environmental conservation programmes for the protected area.

- a completely transparent and inclusive mechanism for grass roots institution building to be established, incorporating in particular the local cultural and moral values, traditions, customs and traditional knowledge, to ensure community participation and involvement in the entire decision-making process.

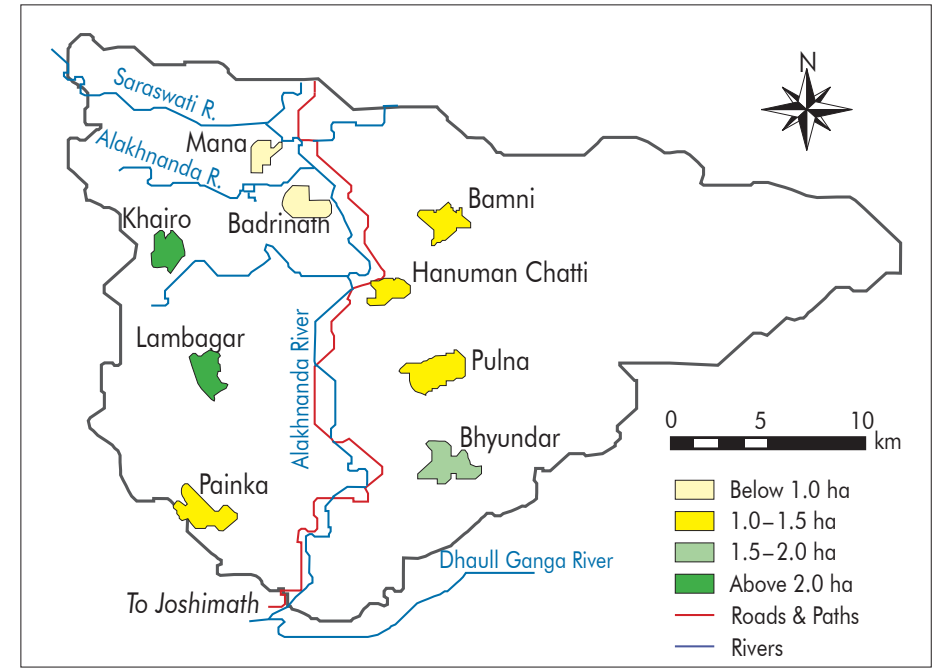

Figure 5 - Cultivated land per capita in NDBR in 2008

development of woollen handicraft with the provision of grazing for sheep on village pastures and in forests. In addition, the cultivation of medicinal and aromatic plants on private as well as common wasteland should emerge as a principal sector of livelihood improvement and income generation programmes within the framework of an integrated resource management strategy. The local people have long-standing experience and knowledge in these practices. However, studies indicate that agriculture would need to be drastically modified to produce medicinal and aromatic plants suitable to local conditions. Since there is an increasing demand for medicinal plants, the local people can easily get a high economic return by cultivating these plants on their agricultural land, and the food deficit can be balanced through import of food grains from outside the region. The wasteland and degraded land and the marginal areas where agriculture is currently being practiced could be diverted to fodder production for sheep and other livestock. Such an integrated conservation-cum-development model has recently been implemented in 'Annapurna Conservation Area' in central Nepal with encouraging results (Rao et al. 2000). A cooperative marketing system will be highly beneficial to promote these sectors in the region.

- empowering local people in the management of natural resources will be imperative to ensure active and effective community participation and involvement in conservation as well as in the process of sustainable development of natural resources.

- limited tourism could be permitted in the buffer zone so that the landless and poor people may generate some income from this traditional sector.

\section{Conclusions}

The closure of access to forests resources transformed the resource utilization pattern and livelihood structure in the NDBR buffer zone, increasing community de- 
pendency on subsistence agriculture in severely limited arable land. As a result, forest resources and pastures became drastically depleted due to land-use intensifications. Nevertheless, agricultural productivity is fairly low, and the region faces a dramatic food shortfall. This has led to an increase in the intensity of agriculture and expansion of agriculture onto marginal and submarginal land, a sign of distress and unsustainable agriculture that people are forced to practise in these circumstances. It is therefore imperative to analyse all crucial issues for conservation and the protection of nature preserves in a holistic manner by considering protected area management as one of the essential components of inclusive development policy. In addition, realistic strategies need to be developed for the desired protection and conservation of the resources biosphere reserve as well as to ensure ecologically sustainable, economically viable and socially acceptable means of livelihood for rural communities who have inhabited the area and preserved the natural landscape for a long period of time and thus have first claim on the resources of the region.

\section{References}

Badola, R. 1995. Nanda Devi Biosphere Reserve: A Study on Socio-economic Aspects for the Sustainable Development of Dependent Population. Project Report, Wildlife Institute of India: Dehradun.

Batisse, M. 1997. Biosphere reserves: A Challenge for Biodiversity Conservation and Regional Development. Environment 6, 14: 6-21.

Bosak, K. 2008. Nature, Conflict and Biodiversity Conservation in the Nanda Devi Biosphere Reserve, Conservation and Society 6, 3: 211-224.

Brown, J. 2002. The Integration of Man and the Biosphere. The Georgetown International Law Review 14, 74: 741-767.

Hoon, V. 1996. Living on the Move: Bhotiya of the Kumaon Himalaya. New Delhi.

Joshi, B. 2006. Natural Resources Information System (NRIS) for Nandadevi Biosphere Reserve Buffer Zone in Upper Alakhnanda Watershed. Project Report, Department of Science \& Technology, Government of India, New Delhi.

Kainthola, S.D., D.S. Rana, N. Singh, P. Naithani, P., S. Kainthola, S. \& B.S. Negi 2005. Community Rights and Livelihoods in the Nanda Devi Biosphere Reserve. International Centre for Integrated Mountain Development (ICIMOD).

Kuhn, M. 2000. Biosphere Reserves as Planning Models for Sustainable Regional Development: Schorfheide-Chorin, Germany. Journal of Environmental Planning and Management 43, 6: 897-904.

Lynagh, F. \& P. Urich 2002. A Critical Review of Buffer Zone Theory and Practice: A Philippine case study. Society and Natural Resources 15: 129-145.

Maikhuri, R.K. , S. Nautiyal , K.S. Rao , K. Chandrasekhar, R. Gavali \& K.G. Saxena 2000. Analysis and Resolution of Protected Area - People Conflicts in Nanda Devi Biosphere Reserve, India. Environmental Conservation 27: 43-53.

Maikhuri, R.K., S. Nautiyal, K.S. Rao \& K.G. Saxena 2001. Conservation Policy - People Conflicts: A Case Study from Nanda Devi Biosphere Reserve. India. Forest Policy and Economics 2: 355-365.

Mitchell, R. 1979. The Analysis of Indian Agro-Ecosystems. New Delhi.

Nand, N. \& K. Kumar 1989. The Holy Himalaya: A Geographical Interpretation of the Garhwal. New Delhi.

Rao K.S., S. Nautiyal, R.K. Maikhuri \& K.G. Saxena 2000. Management Conflicts in the Nanda Devi Biosphere Reserve, India. Mountain Research and Development 20, 4: 320-323.

\section{Author}

Prakash C. Tiwari

Professor of geography at Kumaon University, Nainital, Uttarakhand, India. He is a specialist in natural resource management for mountain areas and in sustainable development. He has worked with a number of institutions in India and abroad.

\section{Bhagwati Joshi}

Assistant professor of geography at the Government Post-Graduate College, Rudrapur (Kumaon University), Uttarakhand, India. She is a specialist in protected mountain area management and has worked with various institutions in India and abroad.

All photographs (C) Prakash Tiwari 